\title{
Materiality, Technology, and Constructing Social Knowledge through Bodily Representation: A View from Prehistoric Guernsey, Channel Islands
}

\author{
SHEILA KoHRING \\ Department of Archaeology and Anthropology, University of Cambridge, UK
}

The role of the human body in the creation of social knowledge-as an ontological and/or aesthetic category — has been applied across social theory. In all these approaches, the body is viewed as a locus for experience and knowledge. If the body is a source of subjective knowledge, then it can also become an important means of creating ontological categories of self and society. The materiality of human representations within art traditions, then, can be interpreted as providing a means for contextualizing and aestheticizing the body in order to produce a symbolic and structural knowledge category. This paper explores the effect of material choices and techniques of production when representing the buman body on how societies order and categorize the world.

Keywords: materiality, body, representation, stone, Channel Islands

\section{EvoKING THE BoDY}

The body as a category for the creation of symbolic and structural, or ontological, knowledge within a given society has been well discussed (e.g. Mauss, 1979; Turner, 1984; Laqueur, 1990; Schilling, 1993; Csordas, 1994; Grosz, 1995; Boyer, 1996; Gilchrist, 2000; Smith, 2004; Nanoglou, 2009a). Thus, displaying the body seems a very personal, emotive act. When we encounter it in representations, the body can evoke a privileged intimacy or intuitive knowledge. Boyer (1996) argues that the body is an intuitive ontological category based on an experiential understanding of self that is projected outwards onto others and onto the physical and material world. Hence, it is a cognitive extension of self and experience to transfer anthropomorphic characteristics and actions onto physical objects. If we imbue objects with anthropomorphic characteristics as part of the cognitive process, it does not seem a great leap to assume, as many do, that these objects can exert some level of agency within society (as discussed by Latour, 1991, 2005; Gell, 1998). Material has its own agency (Ingold, 2007; see also Tilley, 2004) and this agency, along with that of the producer(s), is materialized during the production process. These representations are not static and their agency may be triggered depending on their physical and social context.

The potency of the image rests in the materiality of the representation and engagement with representations within 
social contexts. When the body is materialized in representation, particular structuring principles-or aestheticsaffect choices about what material and technologies are used to make these images (see Nanoglou, 2009b). Aesthetics and structuring principles here are conflated somewhat, but are connected in the sense that they are inherently social, historical, and mediate relationships by expressing idealized principles and practices specific to society (Gell, 1998). Representation of the body, however, is not enough. The body-as-knowledge needs a social context of engagement to structure and frame it. By engaging with representation, a sense of bodily technique and aesthetic emerges and the knowledge transmitted through the category of body is reinforced. These engagements are performed and enacted within social communities that provide the framework for understanding and making both actions and images meaningful. Continued engagement with body representations within their socially appropriate contexts provides meaning to the body. Engagement defines what is an appropriate, essential, and ideal socialized body within that society. New practices may emerge and rework the materialized body, but the images continue to shape social knowledge until they are dispossessed and forgotten.

Understanding knowledge systems through past representations is first and foremost influenced by our own aesthetic of body categories and what they mean to us. But, through contextualizing representations-not as self-evident and static idealized forms, but as active agents in knowledge construction - they materialize ontological categories of the past society. This materialization can be explored through technology, technique, associated practices, and performances. Approaching this through appropriate theoretical frameworks, however, can be achieved in various ways. Two frameworks, in particular, may have pertinence and could be seen to overlap in useful and positive ways: embodiment and corporeality approaches. If we consider how the materiality of human representations can alter perception of the socially meaningful body, we can use the concept of somatic modes of attention to link between ontologies of self and the world around the self (Csordas, 1993: 138). The concept of corporeal realism, or a recognition of the body as a shared biological and social basis through which we experience the world, is helpful in prioritizing the body as a fundamental building block through which knowledge is created as it accepts knowledge as built upon the real and concrete body-in-the-world (see Schilling, 1993, 2005: 12-13). As a starting premise, corporeal realism provides a framework on which we can consider how physical representations of the body might be one way in which societies and communities materialize basic social categories and ontological structures.

The basic premise for this interpretative article arises from the belief that technological practices are an embodied way that people create their physical world and that the human-material-technological relationship is indivisible (Latour, 1991, 2002; Ingold, 2000). I argue that there is a dialectic relationship between the way the body is materially produced and the way the body itself is experienced and conceptualized. As such, the choices in the material used (stone, clay, bone), the techniques employed in the production (painting, incising, chipping) and the setting in which the finished object resides (size and accessibility) all reflect perceptions of the human body as an ontological category within a society. This paper explores the construction of body images in terms of material, technology, and context. It draws upon three examples from the island of Guernsey in the 
Channel Islands (United Kingdom), but is not necessarily exclusive to these examples, and the material and techniques utilized in the production of the bodily images discussed were widespread across the continent and spanned from the Neolithic well into the Iron Age. The recurrence of material and techniques used to create material bodies demonstrates the solidity of these concepts as building blocks for social knowledge systems.

\section{Making Stone Bodies: The Case for Stelae in Prehistoric Guernsey}

The small island of Guernsey lies off the Breton coast of France and is the second largest island in the Channel Islands (Figure 1). Physically separated from the continent since the Mesolithic period, the island was not, however, socially isolated and there is evidence of human activity and occupation on Guernsey spanning from the Palaeolithic to the present (see Sebire, 2005, for an overview). Approximately thirty miles northeast of the French coastline, the community was, by the Neolithic, linked into social networks spanning the western European Atlantic fringe. This connection is evidenced by the shared burial traditions and use of communal chambered tombs such as Le Varde, Le Fouillages, and Le Creux és Faies and by settlements with similar lithic and pottery traditions such as those found recently at Camp Varouf (Garrow \& Sturt, in press) and the airport site (de Jersey, personal communication, 2012).

While settlement and monumental tomb structures tell a story of life and death on the island, the standing stones that remain scattered across the island provide another aspect to understanding community, identity, and society. In particular, several of these standing stones

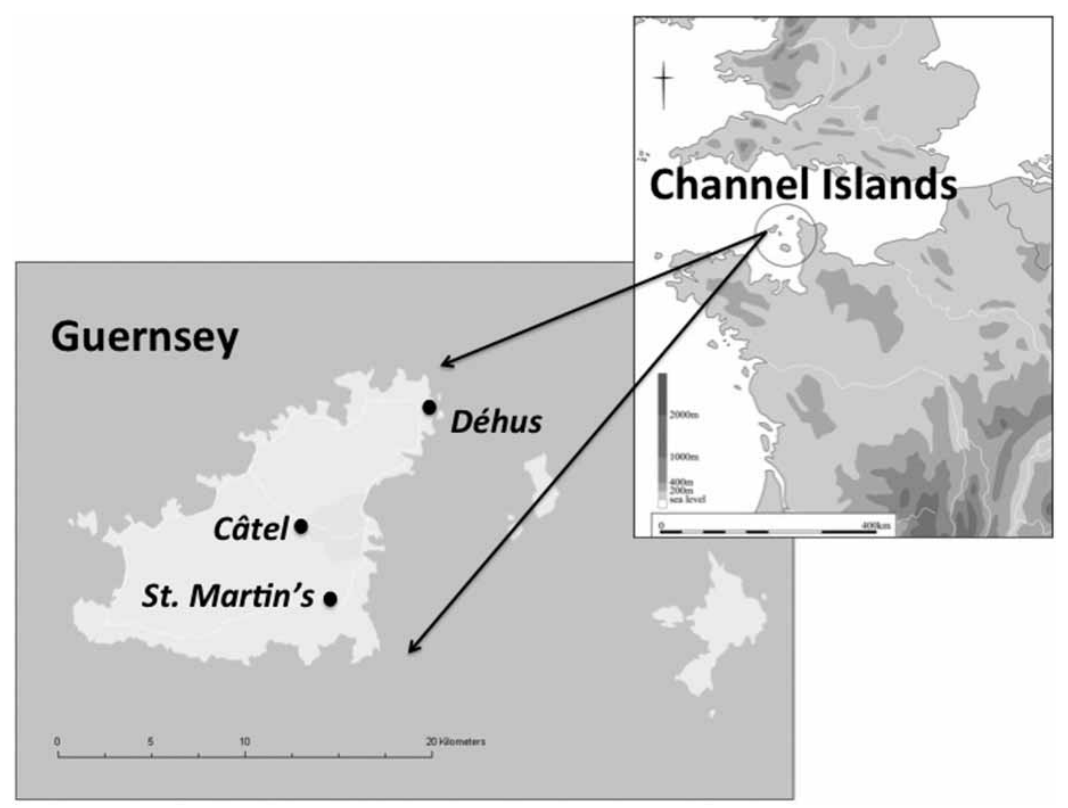

Figure 1. Map of Guernsey, Channel Islands and the location of the three images discussed in the text. Map: K. Boulden and S. Kohring. 


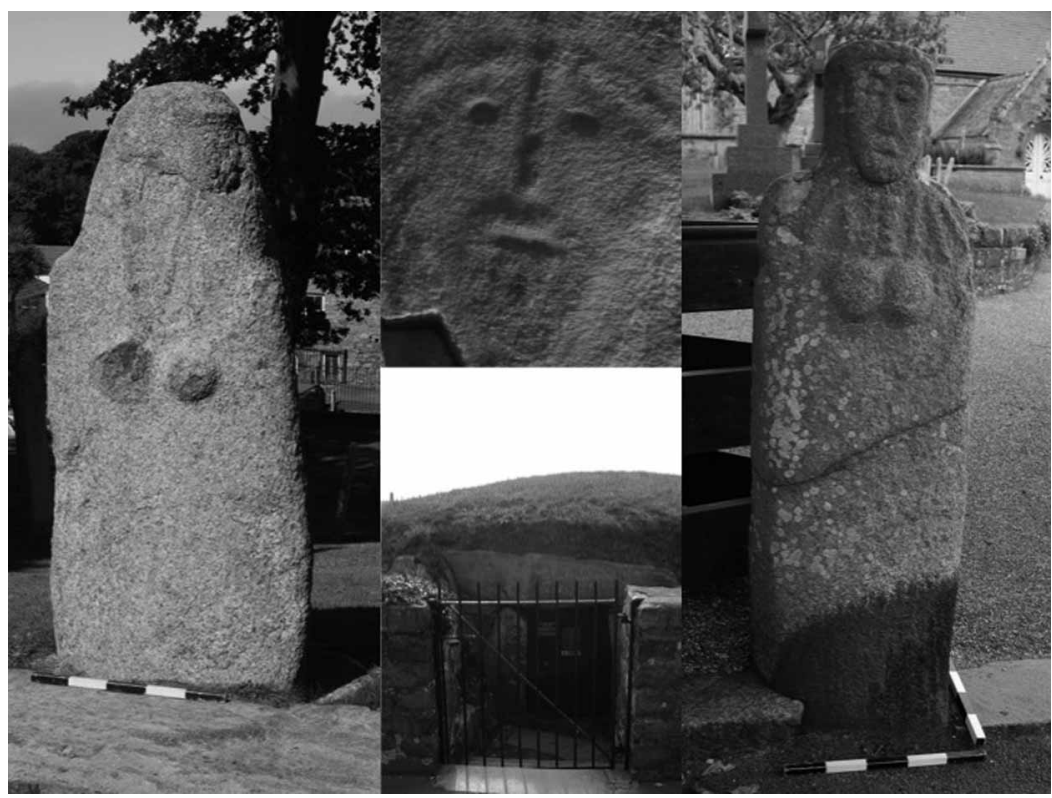

Figure 2. The three bodily images discussed in the text. From left to right: the statue-menhir at Câtel Church, the Débus chambered tomb and gardien, and the statue-menhir at St. Martin's Church. Photos: S. Kohring.

have been shaped into or decorated with anthropomorphic features. Not only can the human representations provide insight into island identity (Kohring, 2013), but their physical presence can tell us about the prehistoric communities' use of the body as an ontological category.

Three surviving human representations provide the clearest evidence for thinking about how their materiality and techniques of production would have influenced the way the body was socially categorized by the prehistoric communities of Guernsey. These comprise the statue-menhir in Câtel churchyard, the engraved imaged of the Gardien du Tombeau on the second capstone of Le Déhus chambered tomb, and the statue-menhir at St. Martin's Church (Figure 2). While these representations are scattered across the island, this does not necessarily reflect their patterning in prehistory as the statue-menhirs may have been moved (both statue-menhirs in this study were re-erected in their current location during the nineteenth century), and the presence of fragmented statuemenhirs, standing stones and megalithic burial monuments reminds us that other images may have been integral to the prehistoric social landscape but have disappeared over time.

For this paper, I want to explore only three ways by which ontological knowledge is constructed through human representation: through choices in material, techniques of production and in the setting, or context, of engagement. Some of these choices reflect local knowledge traditions specific to Guernsey, although most can be extended to traditions of producing and using human body representations that existed in general from the fourth millennium $\mathrm{BC}$ to the first millennium $\mathrm{BC}$ along the western 
Atlantic European fringe. ${ }^{1}$ The human representations on Guernsey overlap and diverge in a range of ways across their materiality, production technique and setting, and all incorporate both local practices and wider cultural aesthetics about the body. These points of intersection and divergence, however, warrant closer attention, and although they are difficult to disentangle I have tried to consider the influence of aesthetics and ontological knowledge exerted during two different stages of the figures' life biographies: production and interaction. In terms of production, I will look at the material and techniques used to create images and how these exerted particular agencies in the creation of a particular kind of image. After the production of the material body, the agency of these representations may have become even more affective in shaping body ontologies; they were the means by which members of the society understood the human form, and they continue to provide this meaning as they influence the way further future images of the body are produced. In this framework, I will consider the importance of setting and context in the past and over time.

\section{Materials}

The use of stone is the starting point for all three bodily representations in the Guernsey case study. While other media may have been utilized in the past and lost to current consideration, this does not negate or reduce the significance of stone

\footnotetext{
${ }^{1}$ The chronology for these figures has been left very general due to the difficulty of dating them, as all their original contexts are unknown. However, the Déhus chambered tomb's early use has been dated between 4100 and $3900 \mathrm{BC}$, which gives us a date to contextualize the gardien on the capstone (see Schulting et al., 2010). Stylistically, the statue-menhirs conform to continental French traditions, dated generally to the fourth and third millennia BC (De Guérin, 1920, and see Robb, 2009).
}

as a material of choice for human representation. In this sense, the use of stone acts as a baseline for human representation on the island. Furthermore, the use of stone panels for rock art and anthropomorphic stelae and statue-menhirs across Europe from the Neolithic to the Iron Age suggests that stone as a medium for human representation had a long history and wide distribution (see edited volumes by Casini et al., 1995, and Casini \& Fossati, 2004, for examples, and Robb, 2009, for an overview).

While weight and transport logistics surely affected choices regarding materials, the prehistoric population on Guernsey, as all the communities along the west Atlantic fringe of Europe, were adept in the working and movement of megalithic stone. Stone's integration as a fundamental architectural element in tombs, as megalithic markers in the landscape and as parts of ritual landscapes was common throughout the Neolithic. As an integral part of constructed life, stone would have had great symbolic potential. While the use of stone as a symbol of duration and permanence is commonly associated with megalithic constructions and stelae/menhir representations, other qualities may have been more significant in prehistoric knowledge systems, and certainly the permanence of stone itself can be questioned. Colour, texture, and natural shape have more recently been considered when discussing the symbolic importance of stones in these constructions during prehistory (e.g. Jones, 1999; Tilley, 2004; Scarre, 2010). On Guernsey, for example, Bukach (2003) found that Neolithic tomb construction integrated material from specific and different stone outcrops on the island. Bukach's (2003) analysis demonstrates that logistical and functional features of material were not the only factors considered in the choice of stone, but that local knowledge was materialized through 

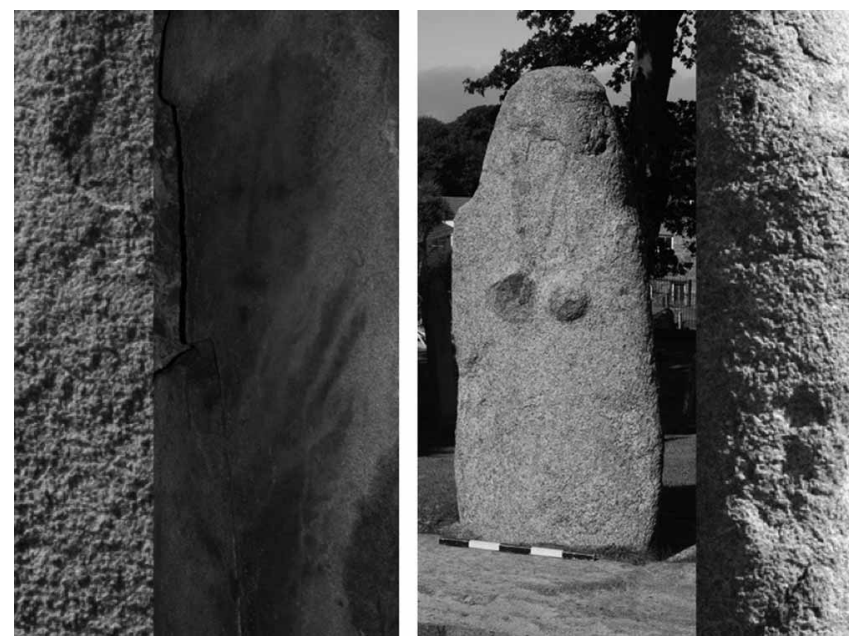

Figure 3. Close-up of stone surfaces. Left-the Gardien du Tombeau; right-the Câtel statue-menhir.

many potential features of material. In most examples, however, different qualities of stone have been discussed for megalithic constructions or rock art rather than as stone used to represent the body.

Looking at the stone representations on Guernsey as an example, all three make use of the local gneisses and granites. While trying to locate their precise origins may be an interesting avenue for future work, I wish to focus on the textural properties of the stone material used for the Guernsey representations. What is striking about these images and their materiality is the rough surface of the stone (Figure 3). Engagement with the stone surface, particularly through touch, would have shaped the comparison with the biological body-either as a contrast or as part of a continuum. The statue-menhir forms, in particular, would have lent themselves to touch, as suggested by their threedimensional carving, life size appearance, and potential for public access. When originally constructed, these figures would have been finished and, in all probability, much smoother to the touch. Unfortunately, reworking has made it difficult to determine if smoother areas are the result of primary or later production and interactions. Furthermore, touch and certain types of engagement (potentially rubbing, painting or dressing of the statue-menhirs) would also have affected their smoothness and feel. Nevertheless, the coarseness and temperature of the stone would have provided a comparative framework for the biological body.

The Déhus figure would also have been evocative in a different way. The figure existed as a menhir prior to its inclusion in the Le Déhus chambered tomb and, as such, it would have been as accessible as both statue-menhirs, although-as a twodimensional figure-its experiencing would have been different. In its final location as a tomb capstone, visual delineation would have been extremely difficult and perhaps simply knowing the image was present was sufficient for its social meaning. However, the granular surface of the menhir/capstone-along with its production technique and setting - suggest touch would have been the most suitable means of knowing the figure, as it is the easiest way to differentiate the concavities of the carving from that of the unworked stone. Thus, the 
individual experiencing the figure's face when in the tomb would have been further constrained in terms of physical engagement by setting and other practices conducted in the tomb. Touch, however, would have been an important way to experience the figure once in the tomb. This would have been a much more personal and intimate tactile experience in comparison to the statue-menhirs both because of the focus on the face and because the dimensionality and setting would have restricted other senses. The rough stone would have provided a strong sensory engagement for constructing the symbolic and comparative nature of the stone bodies: visually seen as bodies but texturally different or 'other'.

The coarse nature of the Guernsey granite makes it difficult, but certainly not impossible, to create fine detail. For example, the St. Martin statue-menhir is the most elaborately detailed of the figures, demonstrating that details can be achieved, although this is due to the reworking of the statue-menhir into a more tabular and deeply engraved figure during the Iron Age or Roman period (Kinnes, 1981). During the Neolithic and Copper Age, however, other types of stone and techniques were known in western Europe and combined to create much more tabular forms with finer details (see d'Anna, 1977; Gallay, 1995; Pedrotti, 1995). In Guernsey, the making of their statue-menhirs and the Déhus figure was potentially constrained by producers' technological knowledge or makers may have chosen to represent in local stone, using particular techniques of production, in order to create a specific local bodily aesthetic in which image detail was left vague and individuality ambiguous. By defining only certain features of the physical body, the producers created a shorthand for a bodily categorization that de-emphasized individuality.
This short-hand arguably transcended the Guernsey community. Recurrent bodily images that are marked by vague facial definition and bodily appendages, while emphasizing body features such as breasts or particular material objects such as necklaces, head pieces, and weaponry, are found in roughly similar forms on many statue-menhirs across Europe during this time (e.g. De Guérin, 1920; Kinnes, 1981, 1995; Casini \& Fossati, 2004; Robb, 2009) and suggest widespread social and gender categories may have been an important aspect materialized through bodily imagery.

Returning to the baseline of corporeal realism and embodiment, Turner (1984) also emphasized the importance of the body as an epistemic as well as an ontological focal point for the construction of meaning. If we consider how the body is conceptualized as a social entity within a society, across Europe we see similar trends in de-emphasizing individuality or in the use of short-hand bodily features regardless of stone material (see Robb, 2009, for a recent overview on regional styles). The use of roughly shaped, large stones for the presentation of the human form provides comparability in terms of size and shape for the statue menhirs. In some instances, anthropomorphically shaped stones have been noted in megalithic tombs (L'Helgouac'h, 1997; Le Roux, 1998; Scarre, 2009); in particular, the capstone with the Déhus figure has been noted as being roughly anthropomorphic in shape (Kinnes, 1981).

In the examples on Guernsey, the two statue menhirs vary in height and size but retain an element of 'life-size' comparability. Standing at $1.60 \mathrm{~m}$ above ground (although the stone is embedded up to 30 $\mathrm{cm}$ further into the ground: Kinnes, 1981: 12), the Câtel statue-menhir is approximately life-size in comparison to the modern female body. While the modern 
female body does not provide intuitive insight into past bodies or body categorization, it does provide a baseline. Furthermore, according to general stature data from Neolithic and Bronze Age Britain, height may have typically varied between 1.57 and $1.72 \mathrm{~m}$ for males and females during these periods (Roberts \& Cox, 2007). Likewise, the St. Martin's statue-menhir currently stands at $1.65 \mathrm{~m}$ above the current paved surface in which she is embedded, although its original height may have been similar to Câtel if they were contemporaneous. It is likely, then, that natural stones were selected because of their size and perhaps their anthropomorphic form or potential. We can see this more clearly in the Déhus figure. The shape of the menhir/capstone on which the figure is pecked, as previously mentioned, is vaguely anthropomorphic although it is not (in contrast to the other two statue-menhirs) life-size, as the maximum height upright as a standing stone is $4.2 \mathrm{~m}$ (Kinnes, 1981: 12). Similarly, if considering only the representation, the face is approximately 50 $\mathrm{cm}$ from browridge to the bottom of the beard and approximately $40 \mathrm{~cm}$ from side to side-substantially larger than a comparable human figure. It appears that the Déhus representation is materializing a different kind of body image and knowledge. In both forms of body knowledge, however, the general stone material used seems to be an important starting point and the natural form of the materialbeing vaguely or socially seen as anthropomorphic - an important or even the most important factor in the selection of material. Hence, highly detailed representation may have been unnecessary and, in fact, the ambiguity created by the coarse material and natural shape of the original stone itself could have affected the symbolic meanings attached to these stone bodies.

\section{Technique}

Two related technologies are most apparent in the production of these images: that of shaping, or dressing, the stone to create figures in the round and that of pecking or grinding of the surface to produce shallow impressions in the stone (Figure 4). These are not the only techniques available for working stone during the Neolithic and Copper Age and other techniques were utilized along the Atlantic coast of Europe during these periods. For example, the painted human images associated with Levantine rock art in eastern and southern Iberia during the early Neolithic provide a very different kind of bodily representation on rock faces during the Neolithic (see Domingo Sanz, 2006). These figures are typically shown in profile and are often shown in movement or performing activities such as hunting or collecting. They are often associated with other bodies, including human and animal forms, within the same or nearby compositions on the same stone panel. While the early Neolithic painted images of the Iberian Peninsula, like the Neolithic images on Guernsey, show little detail regarding overall features of individuals, the technique of painting facilitated a more dynamic and compositional approach to defining the bodies and humans represented. In comparison, the grinding and pecking techniques used by the stone (or body) workers on Guernsey facilitated discrete but unidentifiable bodily forms. These techniques linked the Guernsey community to wider French Atlantic traditions that had their own variations, but similarly utilized coarse stone to facilitate vagueness in feature definition and emphasized particular features when defining the body aesthetic (Kinnes, 1995). The materiality of the granites and gneisses local to Guernsey may not be conducive to finely detailed painted action 


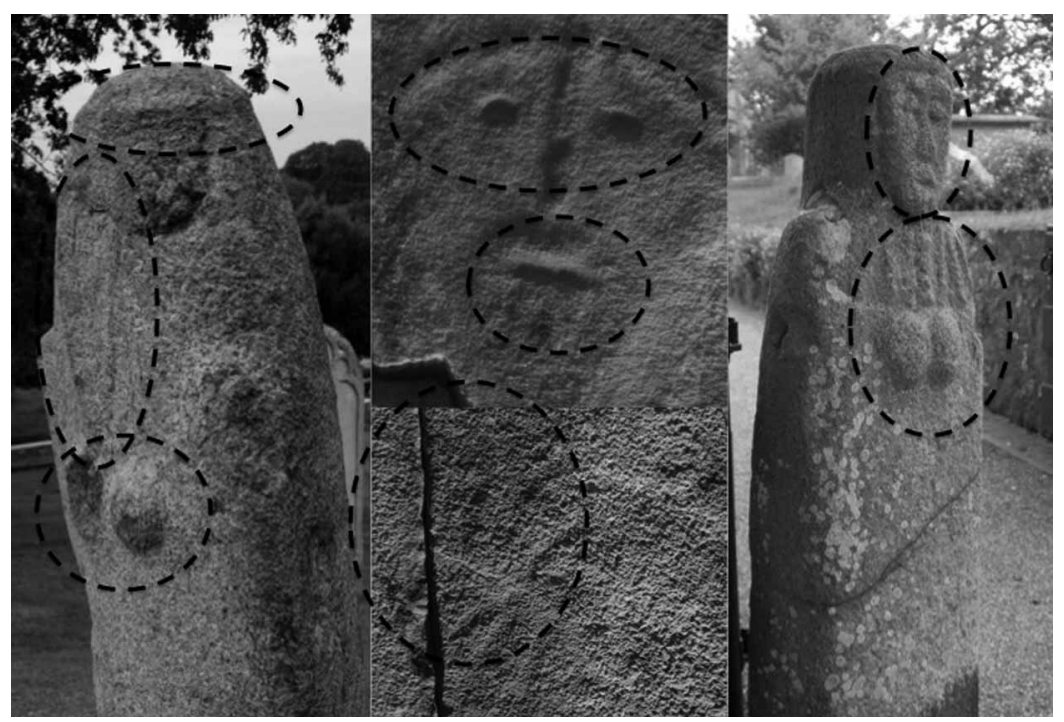

Figure 4. Examples of dressing and pecking techniques used to create anthropomorphic attributes. Left to right: Câtel statue-menbir, Débus figure, St. Martin's statue-menbir.

scenes, but the use of paint is not precluded. Colour is an important aspect to consider, either as added during production or in terms of the stone itself. While there is no indication of painting on the surface of the images, feldspar, part of the island's mineralogy, may have given some freshly dressed stone a slightly pink colouration. However, increasing re-evaluation of megalithic art in Iberia and France indicates that painting was more commonly used alongside engraving and pecking techniques than previously thought (e.g. recent work at Barnenez: Bueno Ramírez et al., 2012). Producing bodies in particular media in combination with particular technologies, such as primarily pecking and grinding, meant detail was shallowly ascribed on the body and the imagery produced was static in its presentation of the ideal social body or body aesthetic.

Looking at the surviving Neolithic images of the Câtel statue-menhir and the Déhus gardien, we have two very different images produced from similar techniques, both producing shallow demarcation of most characteristic details and a reliance on particular key bodily features. One key feature, which is emphasized very differently in the two images, is that of the face. In the case of the Câtel statue-menhir, the face is left purposefully flat and featureless with only the head being delineated by its separation from the shoulders and a band encircling the top of the head. This is the 'classic' representational style for statuemenhirs in the wider French Atlantic region and implies a shared aesthetic regarding the construction of these figures (see Kinnes, 1995; Kohring, 2013). It is possible that paint, dress, or masks could have been used in combination with the static body in order to make the figure more contextually dynamic, but if these techniques and materials were used they have left no evidence. Importantly, the Câtel statue-menhir and similar French statue-menhirs were shaped in order to emphasize bodily features by standing out against the backdrop of the stone body. These include the head, neck, and breasts, 
although other features are marked very generally, such as the shoulders, arms, and back. In contrast, the Déhus figure's primary bodily reference point is the face. Shallow pecking and grinding techniques created contoured features, such as the brow ridge, eyes, mouth, and beard, which were only approximately $0.3 \mathrm{~cm}$ in depth (Kinnes, 1981: 12). Arms and a bow were again loosely associated with this form, but it was the face that dominated the panel in its final, and probably earlier, contexts. Thus, it appears that only particular features of the body were intentionally produced and this suggests their fundamental role in categorization of the body as a source of knowledge.

Finally, the techniques of pecking and grinding may have created a sense of temporal knowledge of the body. The act of grinding and pecking would have had a different temporality, compared with techniques such as painting, in the chaine opératoire of producing these bodies. The producer(s) would have had to spend time slowly grinding away stone to expose the social body within it. If we consider how knowledge becomes attached to body categories, we can consider that ideas of 'making the body' may have resulted in a comparable idea regarding the time required to make an appropriate human body as well. The social body was to be moulded, touched and taught to be human-potentially, both in flesh or in stone. Hence, physical making, practice, and engagement with stone bodies provided a sense of making human bodies as well.

More generally, the shallow nature of bodily attributes structuring the bodily knowledge of Câtel and Déhus, and their slightly fuzzy boundaries, may have encouraged tactile engagement with the bodily images. The shallow concavity of the Déhus image, combined with the restricted setting in its final context, which requires artificial light for viewing the figure, would have been difficult to access in any other sensory way. However, even if the figure had been primarily engaged with as a standing menhir prior to its inclusion in the tomb, the size and shallow pecking techniques may have been even more difficult to interact with. Touch was certainly still important, but it would have been fundamentally different than that of the two statue-menhirs. The relief techniques of Câtel may also prioritize touch as a primary means of engagement. In this instance, it may be the prominence of certain features acting as mnemonics for body narratives. By touch, you would firstly know that the image was a 'body' through the emphasis on the torso or the face. Based on the prioritized features, individuals could then attach appropriate social categories to these images, aiding in shaping the practices and contexts of engagement within their social setting.

Over time, new technological traditions and practices emerge. A different type of deeply applied relief technique was used to rework the St. Martin's statue-menhir, compared to those employed earlier in the Neolithic. The technique of deeper incision of motifs allowed for greater definitions of lines, and the creation of detail is clearly demonstrated in the St. Martin figure's hairstyle and elaborate cloak. These new stoneworking techniques may have required different tools and they definitely require different body techniques for their production. Metal, or hard chisels, would be required to create a deeper and finer cut into the granite stone. The body of the producer would have had to be positioned differently than with the earlier technical practices of the Neolithic. Hence, compared to these earlier production techniques, the producer(s) of the reworked St. Martin's statue-menhir would have had a different techniques $d u$ corps, or bodily movement, than the original imaginer of the figure. Thus, making 
the new St. Martin's statue-menhir accentuated the body of the producer in a different way than that of their ancestors. On the other hand, the action of producing different bodily details in the reworked figure suggests that a new bodily experience and knowledge system was already being established.

\section{Setring}

Techniques and material, combined with a sense of embodiment and corporeal realism, create a particular aesthetic of the body and materialize a shared social meaning through the body. The social context for human representation accentuates the symbolic significance of bodies by framing the types of engagements possible between biological and material bodies. Settings are not, however, separate from material and technology as often the choices made during production affect the possibility of setting and presentation. For example, the production in stone, especially in large blocks, affects the mobility of all three Guernsey representations. The Déhus figure's final context is perhaps the most restricted setting in this sense. The chambers are now covered by a restored large circular earthen mound and kerbstone construction. In the interior, there is a passage and large central chamber with four to six side chambers. When first excavated in the nineteenth century, the chambers were recorded as filled with limpet shells covering human bone and pottery (Sebire, 2005; Schulting et al., 2010). The image itself is located on the second to last capstone in the main chamber of the tomb and was part of the original structure. The weight of the stone would have made moving this image or changing the mode of engagement with it a very difficult and elaborate community event. The fact that the community chose to move the Déhus stone from an upright standing stone to an architectural feature is not an uncommon practice, but it does suggest that the stone and/or image was of particular significance. That is not to say that both statue-menhirs would have been moveable without group coordination, as their weight is a significant contrast in relation to their (approximately) human heights (see also Robb, 2009). The fact that movement of these images would have required community (perhaps even several communities) coordination may have been a rationale for their movement or alteration in the past. In fact, in all three Guernsey cases, we know that all these stone images have been moved. The Déhus gardien was produced on the stone surface of the capstone prior to its integration into the tomb architecture during the Neolithic, and both statue-menhirs were buried or integrated into existing architecture before being re-erected in nearby churchyards in more recent history.

The context of the Déhus figure is perhaps equally striking in the constrained manner in which it had to be engaged with by the producing and later Guernsey population. While it could be argued that the change in setting suggests disuse or destruction of the figure's meaning, I would argue the opposite. Once in its location in the Déhus chambered tomb, the gardien's was an affective presence, shaping the experience of visitors to the tomb during the interment of the dead by engaging the senses in very specific ways. Touch would have been important and it may be one reason why facial features were used to create body knowledge in this instance. In considering how individuals read social context in meaningful ways, Goffman (1963: 89) has emphasized the importance of the face in signalling 'mutual activity', which provides a social context for interaction across social statuses and positions. While Goffman 
(1963) emphasizes verbal communication and facial engagement, I believe that the corporeality of faces in culturally charged media, such as stone in the Guernsey examples, would also evoke bodily knowledge and symbolism and further suggests the image was integrated there with deliberate intention. Knowing, through touching the face of the gardien, would have recreated an intimate power relationship between human and stone. The liminality of the setting and the intimacy of the engagement suggests that the gardien had an important role spanning between the living bodies and the dead as mediated through the stone image.

If we think about the bodily categorization of gender in reference to the three images, setting reinforces technical, and representational styles. The difference in setting between the Déhus gardien and the two statue-menhirs suggests that some sort of gendered division may be being expressed. Different kinds of body images and knowledges, which may have to do with sex or gender, were potentially used for different social settings. While we cannot assume open access for the statuemenhirs, their size, shaping, and rediscovery in open or social contexts suggest they would have played a more public role in prehistoric society. The gardien, commonly referred to as male-although this is due to our own reading of material associations and facial features-appears in this final setting to be more private or restricted in its access. As a note on our ascription of gender associations, it is interesting that when the gardien was first rediscovered, it was compared to the Câtel and St. Martin statue-menhirs and discussed in female terms (see De Guérin, 1920). What is evident is that different bodies, emphasizing different bodily characteristic and material associations, were made differently and situated in different social contexts—some potentially more public and others more private. If we presume we can read some sort of engendering of these figures, then it demonstrates that our common duality between male/female and public/private is not static structural knowledge categories. Laqueur's (1990) history of sex is a clear reminder that there is no essentialized meaning or duality between sexes and, for that matter, gender, and that these ontologies change over time. The change in imagery of the St. Martin statue-menhir and the setting of the Déhus menhir/capstone may be taken as examples of changing gender, as well as body, categories over time.

A final consideration of setting can be discussed in terms of temporality. While the current surface of the Câtel statuemenhir is the result of many years of use, re-use, and wear on these stone images, it reminds us that stone is a dynamic medium with its own agency (Ingold, 2007). The material agency, or perhaps more appropriately in this sense the corporeality, of the representation in stone continues to be expressed once established in its social setting. Changes due to reworking or weathering may have been linked to ideas about the human lifecycle. If we compare the two female gendered (by our standards) statue-menhirs of Câtel and St. Martin, their setting and context may have been a further contributing factor to the process of aging that would have slowly occurred over time. As the Câtel statue-menhir currently stands, the material properties of the stone give it a very grey appearance and the coarse grain makes boundary lines blurry. If the statuemenhir had originally or often been set in open contexts and exposed to the elements, it is very likely that this process would have started fairly early in its life biography. In comparison, the explicit reworking of the St. Martin's statue-menhir reflects the need or desire to rejuvenate and 
provide a new social status to this image; in essence, re-birthing a new body concept and knowledge through appropriation of the public, and aged, ancestor.

\section{Conclusions: MaKing}

When we look at a Renaissance painting we idealize the bodies and attach particular aesthetic qualities and symbolic meanings to them. Even after body images start to change, these aesthetics and symbolic meanings surrounding the body often persist within social knowledge structures. A scan of the internet for 'Botticelli' makes it quickly apparent that the bodily imagery this invokes remains a positive ideal. Botticelli may have been materializing a body image relevant to his time, but the persistence of the symbolic aesthetic of beauty built around the female form continues to inform present knowledge even though the body image has changed. One reason for this is that the representation, or art, persists beyond its originator and continues to exert its agency within society (Gell, 1998). Human representations in material form can persist within social contexts and shape social ontologies by providing anchors for categorical knowledge.

The figures I discuss here are not meant to provide a comprehensive picture, but, rather, to provide insight-especially when contextualized within shared European representational traditions during prehistory-into how Neolithic and Bronze Age bodies were constructed and used. It also allows us to question how representing the body in particular media-in this case stone-may have shaped past societies' views on the body by creating associated knowledge around peoples' place in the world, the permanence or ephemerality of the body, the discreteness or fluidity of the body, and the ability of the body to be reworked and re-symbolized throughout its life biography. Corporeal realism and embodiment theories provide a link between the use of the body and the creation of ontological categories and knowledge of the world. In effect, understanding the materiality and techniques of imagery allow us insight into the aesthetic categorization of the body in prehistoric Guernsey society.

\section{REFERENCES}

Boyer, P. 1996. What Makes Anthropomorphism Natural: Intuitive Ontology and Cultural Representations. Journal of the Royal Anthropological Institute, n.s. 2:1-15.

Bueno Ramírez, P., de Balbín Behrmann, R., Laporte, L., Bouezin, P., Barroso Bermejo, R., Hernanz Gismero, A., Gavira-Vallejo, J. \& Iriarte Cela, M. 2012. Paintings in Atlantic Megalithic Art: Barnenez. Trabajos de Prehistoria, 69 (1):123-32.

Bukach, D. 2003. Exploring Identity and Place: An Analysis of the Provenance of Passage Grave Stones on Guernsey and Jersey in the Middle Neolithic. Oxford Journal of Archaeology, 22(1):23-33.

Casini, S., de Marinis, R.C. \& Pedrotti, A. 1995. Statue-Stele e massi Incisi nell'Europa dell'Età del Rame. Notizie Archaeologiche Bergomensi 3. Bergamo: Civico Museo Archaelogico.

Casini, S. \& Fossati, A. 2004. La Pietre degli Dei: Statue-Stele dell'Età del Rame in Europa - lo Stato della Ricerca. Notizie Archaeologiche Bergomensi 12. Bergamo: Civico Museo Archeologico.

Csordas, T.J. 1993. Somatic Modes of Attention. Cultural Anthropology, 8(2):135-56.

Csordas, T.J. 1994. Introduction: The Body as Representation and Being-in-the-World. In: T.J. Csordas, ed. Embodiment and Experience: The Existential Ground of Culture and Self. Cambridge: Cambridge University Press, pp. 1-24.

d'Anna, A. 1977. Les statues-menbirs et steles anthropomorphes du midi méditerranéen. Paris: Centre National de la Recherche Scientifique.

De Guérin, T.W.M. 1920. Notes on the Recent Discovery of a Human 
Figure Sculptured on a Capstone of the Dolmen of Déhus, Guernsey. Man, 20:129-34.

Domingo Sanz, I. 2006. La figura humana, paradigma de continuidad y cambio en el arte rupestre Levantino. Archivo de Prehistoria Levantina, 26:161-91.

Gallay, A. 1995. Les stele anthropomorphes du site mégalithique du Petit-Chasseur à Sion (Valais, Suisse). In: S. Casini, R. C. de Marinis \& A. Pedrotti, eds. Statue-stele e Massi Incisi nell'Europa dell'Età del Rame. Notizie Archeologiche Bergomensi 3. Bergamo: Civico Museo Archeologico, pp. 167-94.

Garrow, D. \& Sturt, F. in press. The Mesolithic-Neolithic Transition in the Channel Islands: Maritime and Terrestrial Perspectives. In: T. Darvill \& A. Sheridan, eds. Hands Across the Water: The Archaeology of the Cross-Channel Neolithic. London: British Academy.

Gell, A. 1998. Art and Agency: Towards a New Anthropological Theory. Oxford: Clarendon Press.

Gilchrist, R. 2000. Unsexing the Body: The Interior Sexuality of Medieval Religious Women. In: R. Schmidt \& B. Voss, eds. Archaeologies of Sexuality. London: Routledge, pp. 89-103.

Goffman, E. 1963. Behavior in Public Places: Notes on the Social Organization of Gatherings. New York: The Free Press.

Grosz, E. 1995. Space, Time, and Perversion: Essays on the Politics of Bodies. London: Routledge.

Ingold, T. 2000. Making Culture and Weaving the World. In: P.M. GravesBrown, ed. Matter, Materiality and Modern Culture. London: Routledge, pp. $50-71$.

Ingold, T. 2007. Materials Against Materiality. Archaeological Dialogues, 14(1):1-16.

Jones, A. 1999. Local Colour: Megalithic Architecture and Colour Symbolism in Neolithic Arran. Oxford Journal of Archaeology, 18(4):339-50.

Kinnes, I. 1981. The Art of the Exceptional: The Statue-Menhir of Guernsey in Context. Archaeologia Atlantica, 3:9-33.

Kinnes, I. 1995. Statue-Menhirs and Allied Representations in Northern France and the Channel Islands. In: S. Casini, R.C. de Marinis \& A. Pedrotti, eds. Statue-Stele e massi Incisi nell'Europa dell'Età del Rame.
Notizie Archeologiche Bergomensi 3. Bergamo: Civico Museo Archeologico, pp. 131-41.

Kohring, S. 2013. Stepping Stones: Art and Community on Prehistoric Guernsey, Channel Islands. Journal of World Art, 3 (2):297-318.

Laqueur, T. 1990. Making Sex: Body and Gender from the Greeks to Freud. Cambridge: Harvard University Press.

Latour, B. 1991. Technology is Society Made Durable. In: J. Law, ed. A Sociology of Monsters: Essays on Power, Technology and Domination. London: Routledge, pp. 103-31.

Latour, B. 2002. Morality and Technology: The Ends of the Means. Trans. C. Venn. Theory, Culture \&o Society, 19(5/6):24760.

Latour, B. 2005. Reassembling the Social: An Introduction to Actor-Network-Theory. Oxford: Oxford University Press.

Le Roux, C.-T. 1998. Du menhir à la statue dans le mégalithisme armoricain. In: J. Guilaine, ed. Actes du 2ème Colloque International sur la Statuaire Mégalithique, Saint-Pons-de-Thommières du 10 au 14 septembre 1997. Archéologie en Languedoc 22, pp. $217-35$

L'Helgouac'h, J. 1997. De la lumière au ténèbres. In: J. L'Helgouac'h, C.-T. Le Roux \& J. Lecornec, eds. Art et Symboles du Mégalithisme Européen. Actes du 2ème Colloque International sur l'Art Mégalithique, Nantes 1995. Revue Archéologique de l'Ouest, supplément 8. Rennes: Association pour la Diffusion des Recherches Archéologiques dans l'Ouest de la France, pp. 107-23.

Mauss, M. 1979. The Notion of Body Techniques. In: Sociology and Psychology: Essays by Marcel Mauss. Trans. Brewster. B. London: Routledge and Kegan Paul, pp. 95-123.

Nanoglou, S. 2009a. Representing People, Constituting Worlds: Multiple 'Neolithics' in the Southern Balkans. Documenta Praehistorica, 36:283-97.

Nanoglou, S. 2009b. The Materiality of Representation: A Preface. Journal of Archaeological Method and Theory, 16:15761.

Pedrotti, A. 1995. Le Statue Stele de Arco: La Statuaria Antropomorfa Alpina nel III Mellennio AC: Abbigliamento, Fibre Tessili 
e Colore. Trento: Museo Civico di Riva del Garda.

Robb, J. 2009. People of Stone: Stelae, Personhood, and Society in Prehistoric Europe. Journal of Archaeological Method and Theory, 16:162-83.

Roberts, C. \& Cox, M. 2007. The Impact of Economic Intensification and Social Complexity on Human Health in Britain from 6000 BP (Neolithic) and the Introduction of Farming in the Mid-Nineteenth Century. In: M. Cohen \& G.M. Crane-Kramer, eds. Ancient Health: Skeletal Indicators and Economic Intensification. Gainesville: University Press of Florida, pp. 149-63.

Scarre, C. 2009. Stones with Character: Animism, Agency and Megalithic Monuments. In: B. O'Connor, G. Cooney \& J. Chapman, eds. Materialitas: Working Stone, Carving Identity. Oxford: Oxbow Books, pp. 9-18.

Scarre, C. 2010. Megaliths, Memory and the Power of Stones. In: D. Calado, M. Baldia \& M. Boulanger, eds. Monumental Questions: Prehistoric Megaliths, Mounds and Enclosures. Oxford: Archaeopress, pp. 91-96.

Schilling, C. 1993. The Body and Social Theory. London: SAGE.

Schilling, C. 2005. The Body in Culture, Technology and Society. London: SAGE.

Schulting, R.J., Sebire, H. \& Robb, J.E. 2010.

On the Road to Paradis: New Insights from AMS Dating and Stable Isotopes at Le Déhus, Guernsey and the Channel Islands Middle Neolithic. Oxford Journal of Archaeology, 29(2):149-73.
Sebire, H. 2005. The Archaeology and Early History of the Channel Islands. Stroud: Tempus.

Smith, P. 2004. The Body of the Artisan: Art and Experience in the Scientific Revolution. Chicago: University of Chicago Press.

Tilley, C. 2004. The Materiality of Stone: Explorations in Landscape Phenomenology. Oxford: Berg Publishers.

Turner, B.S. 1984. The Body and Society: Exploration in Social Theory. Oxford: Basil Blackwell.

\section{Biographical Note}

Sheila Kohring is an Affiliated Lecturer at the University of Cambridge and Research Associate at Clare College, Cambridge. Her research interests include technological practices and the construction of social knowledge. Her work in the Channel Islands was supported by the McDonald Institute for Archaeological Research. She is currently involved in the Anthropology of Prehistoric Health project sponsored by the Wellcome Trust.

Address: Department of Archaeology and Anthropology, Downing Street, University of Cambridge, Cambridge, CB23DZ, UK. [email: sek34@cam.ac.uk]

\section{Matérialité, technologie et construction de l'intelligence du corps: perspective de l'île préhistorique de Guernesey (île anglo-normande)}

Le rôle du corps dans la création du savoir social — comme catégorie ontologique etlou esthétique - a été largement appliqué en théorie sociale. Toutes ces approches considèrent le corps comme un lieu de prédilection pour l'expérience et le savoir; il devient un instrument important pour créer des catégories ontologiques du soi et de la société. La matérialité des représentations humaines au sein des traditions artistiques peut alors être interprétée comme constituant un moyen de contextualisation et d'esthétisation du corps afin de produire une catégorie de savoir symbolique et structurel. Dans cet article nous examinons l'effet des choix de matériaux et des techniques de production lors de la représentation du corps bumain sur la manière dont les sociétés classent et catégorisent le monde. Translation by Isabelle Gerges

Mots-clés: matérialité, corps, représentation, pierre, îles anglo-normandes 


\section{Materialität, Technologie und die Konstruktion des Körpers als Quelle von Erkenntnis: Eine Perspektive vom vorgeschichtlichen Guernsey, Kanalinseln}

Die Rolle des menschlichen Körpers bei der Schaffung sozialen Wissens - als ontologische und/oder ästhetische Kategorie - fand in der Sozialtheorie stets Berücksichtigung. Bei all diesen Ansätzen wird der Körper als Ort der Erfahrungen und des Wissens angesehen; und er wird ein wichtiges Instrument der Erhebung ontologischer Kategorien des Selbst und der Gesellschaft. Die Materialität menschlicher Darstellungen in den Felskunst-Traditionen kann somit als Hilfsmittel für die Kontextualisierung und Ästhetisierung des Körpers angesehen werden, um eine symbolische und strukturelle Wissenskategorie zu schaffen. Dieser Beitrag untersucht den Effekt der Materialwabl und der Produktionstechniken bei der Abbildung des menschlichen Körpers in Hinblick darauf, wie Gesellschaften die Welt gliedern und kategorisieren. Translation by Heiner Schwarzberg

Stichworte: Materialität, Körper, Repräsentation, Stein, Kanalinseln 